\title{
GAGUEIRA: UMA QUESTÃO DISCURSIVA
}

\author{
A STUTTERING: A MATTER OF DISCOURSE
}

\author{
Regina Maria Freire* \\ Maria Cristina Pascalicchio Passos
}

\section{RESUMO}

Este artigo propõe um dispositivo para teorizar a gagueira. Supõe-se que a gagueira emergiria na terceira posição do processo de aquisição de linguagem, quando podem ser observadas, nas produções das crianças, pausas, reformulações e autocorreções. Essas pausas, reformulações e autocorreções assemelham-se às repetições e hesitações que caracterizam a gagueira, gerando movimentos de estranhamento no Outro (Termo definido por Lacan como sendo o lugar do "tesouro dos significantes" ou o lugar do outro simbólico que afasta da cena o outro encarnado). Esse estranhamento pode levá-Lo a atribuir a essas repetições, pausas e hesitações, o estatuto de gagueira, ou seja, a cristalizar o manifesto, aprisionando-o ao patológico. Para dar sustentação a essa hipótese, entrevistaram-se as mães de quatro crianças gagas, cujos dizeres foram analisados alçando-se o dispositivo da Análise de Discurso de Linha francesa. Os achados apontam para os efeitos da interpretação do Outro sobre o gago e a urgência de se levar em conta a submissão da criança a um discurso, predominantemente autoritário. Concluindo, ao pensar a gênese da gagueira, seria primordial levar em conta: a) a interpretação que o Outro faz da fala da criança; b) como a criança ouve sua própria fala e c) a sobre determinação simbólica da linguagem - resignificando repetições e hesitações como inerentes ao processo de aquisição da linguagem pela criança.

Palavras-chave: análise de discurso; gagueira; aquisição de linguagem.

\section{ABSTRACT}

This paper proposes a framework for theorizing about the emergence of stuttering. The implication is that stuttering emerges in the third discursive position of the language acquisition process. In this phase, one can observe pauses, reformulations and selfcorrections in children's productions. Because these actions resemble the repetitions and hesitations that characterize stuttering, they lead the other to erroneously attach a pathological interpretation to a set of no pathological events. If the other sees the child as a stutterer, it's still at least partly up to the child to fulfil that role or not. Whether the child does so depends on whether (s)he sees (her)himself as a stutterer. If the child does,

\footnotetext{
* PUC-SP, São Paulo (SP), Brasil. freireregina@uol.com.br; ** PUC-SP, São Paulo (SP), Brasil. posfono@pucsp.br
} 
further interpretations of his/her speech will be from the context of this role. To support this hypothesis we interviewed the mothers of four children and analysed their discourse based on the French School of Discourse Analysis. The analysis showed the interpretation's effects on the stutterer and points to the need to delineate the child's susceptibility to the effects of the speech of the mother. In conclusion, when thinking about the genesis of stuttering, one should consider three important points: (a) the other's interpretation of the child's speech, (b) what the child hears of his/her own speech, and (c) the symbolic over determination of language - considering repetitions and hesitations as inherent to language acquisition in the child.

Keywords: discourse analysis; stuttering; language acquisition.

\section{INTRODUÇÃO}

A gagueira, cuja incidência é de $1 \%$, tanto na população pré-escolar quanto na população adulta (PORFERT e ROSENFIELD, 1978; ANDREWS et al, 1983; ADAMS, 1988), vem sendo objeto de investigação científica há muito tempo. Os primeiros estudos datam dos séculos XVIII e XIX, quando era identificada como um distúrbio no aparelho respiratório ou nos órgãos da fala - cujo tratamento era cirúrgico. A primeira abordagem não-cirúrgica dessa patologia foi proposta por Hunt, em 1860 (IRWIN, 1983). Sua técnica, cuja intervenção se situa fora do campo da medicina, consistia em ensinar os pacientes a falar conscientemente, controlando suas produções. De acordo com Irwin (op. cit, p.8) "não se conhecem detalhes sobre esse tratamento, pois o Dr. Hunt acreditava que o segredo do sucesso estava na aplicação do sistema e não no sistema em si".

Durante o século XX, foram desenvolvidas muitas pesquisas sobre a gagueira, assentadas, em sua maioria, sobre o modelo lógico positivista que trabalha com os fenômenos em seu aspecto aparente, pautando-se por uma perspectiva linear, isto é, pela busca de causas e efeitos a fim de controlar e prever os acontecimentos.

O primeiro estudo positivista, mundialmente conhecido, foi o de Van Riper (1963), que trouxe avanços ao descrever a gagueira além de suas possíveis origens e de seu desenvolvimento, ou seja, propondo uma forma de intervenção terapêutica. Em seus estudos, a gagueira é vista como uma alteração da fala e a técnica de intervenção é o trabalho com os aspectos prosódicos - ritmo, fluência e velocidade - e articulatórios, sendo então a terapêutica voltada para o condicionamento de uma nova forma da fala. Segundo o autor (p.15), "a gagueira ocorre quando o fluxo de fala é interrompido pela ruptura motora de um som, sílaba ou palavra quebrada ou pelas reações do falante a isto". 
No Brasil, em oposição ao paradigma proposto por Van Riper, Meira (1983) estudou a gagueira dentro da lógica fenomenológica. Sua oposição surgiu, principalmente, ao observar que Van Riper aponta para esse problema como um fato, recortando o que se mostra de imediato, sem, no entanto, se deter para descrever o que pode ser visto além da aparência.

Diferentemente dessa posição, a lógica fenomenológica busca a essência dos fenômenos, aquilo que não se vê em sua aparência, aquilo que não se quantifica ou não se mede. Para se apreender os fenômenos em sua essência é necessário fazer a redução fenomenológica, ou seja, a negação de todo o conhecimento prévio sobre o fenômeno foco de estudo para, a partir da negação de tudo o que já se conhece, poder apreender o fenômeno no que ele tem de essencial. Assim, para Meira (op. cit.), a gagueira é considerada um fenômeno restrito aos invólucros de tensão, posição que privilegia o corpo como objeto de estudo, e propõe uma terapêutica centrada no trabalho corporal. Nessa abordagem, a gagueira enquanto fato se distingue da gagueira enquanto fenômeno, ocultado pelos invólucros ou tensões que evidenciam a primeira.

Friedman (2004) afirma que a gagueira é construída de fora para dentro, como conseqüência da interpretação que o outro faz do padrão de fala disfluente da criança, sendo essa interpretação influenciada por uma representação estigmatizada da disfluência - a ideologia do bem falar. Segundo a autora (2009, p.7) "quando esta representação se manifesta sistematicamente na relação dialógica, acaba interferindo no desenvolvimento da criança, já que ela, a partir do outro, se constrói como falante estigmatizado e, desse lugar, passa a impedir-se de falar e passa a viver a fala como sofrimento, o que transforma e transtorna sua forma espontânea de falar". A terapêutica, nessa perspectiva, visa à reconstrução da identidade desse gago, na busca de conscientizá-lo a não precisar mais se utilizar da gagueira nas situações consideradas ameaçadoras.

Azevedo e Freire (2001) partem do pressuposto de que uma disciplina nasce como ciência quando circunscreve um objeto e entendem que a Fonoaudiologia deu o primeiro passo ao circunscrever a clínica dos sintomas de linguagem como seu objeto. Do alçamento da linguagem da periferia para o centro da cena, estrutura-se uma proposta alternativa de se pesquisar a gagueira enquanto questão discursiva. Como esta proposta servirá de base para o que desenvolveremos aqui, será detalhada na próxima seção.

À semelhança do que ocorre nos estudos sobre a gagueira, ao se circunscrever a conceituação de disfluência normal de fala ou disfluência de desenvolvimento ou, ainda, gagueira fisiológica, é possível encontrar diversas posições, prevalecendo aquelas assentadas sobre a lógica positivista. 
Van Riper (1963) afirma que a gagueira muda de forma à medida que se desenvolve. Para o autor, a gagueira desenvolve-se em quatro estágios. O primeiro é chamado de disfluência e caracteriza-se pelo fato de a criança não ter consciência. No segundo estágio, a criança começa a ter consciência; no terceiro, sente-se frustrada. No quarto, o de gagueira secundária, a pessoa, conscientemente, começa a temê-la e lutar contra ela.

Nos estudos de Johnson (1959), Bloodstein (1971) e Berthodin (apud GOMES, 1991), encontra-se a mesma visão desenvolvimentista sobre a gagueira. Bloodstein (op. cit.) define a disfluência normal como a fase I do desenvolvimento da gagueira, que também tem quatro fases. De acordo com Berthodin (op. cit.), a disfluência normal de fala aparece durante o período de aquisição de linguagem por volta dos três anos de idade - durando, no máximo, seis meses, com remissão espontânea. A gagueira patológica pode ou não aparecer nesse mesmo período, mas sua principal característica está na ultrapassagem da duração de seis meses, com o momento da fala sendo acompanhado de tensão e espasmos. Esse autor, assim como Bloodstein (op. cit.), descreve a gagueira em fases, mas não explicita as causas de seu aparecimento / desaparecimento.

Friedman (2004) pesquisou, de forma minuciosa, a gênese da gagueira. De acordo com seu estudo, pode-se diferenciar a gagueira sofrimento da gagueira natural. A gagueira natural é entendida como uma característica inalienável da produção de fala, correspondente à chamada disfluência normal de fala. Esta gagueira não se faz acompanhada da imagem estigmatizada do falante, sendo um padrão que pode ser encontrado na fala de qualquer pessoa, criança ou adulto, dependendo da situação de fala; dos valores que o indivíduo atribui a si mesmo e à situação; de seu estado emocional e do grau de envolvimento ou domínio do assunto que se fala.

Essa gagueira natural pode se transformar em gagueira sofrimento, em conseqüência de situações paradoxais de comunicação. Estas são entendidas como paradoxais porque levam o indivíduo a um duplo vínculo: ele não pode sair da situação em que se encontra (já que a fala, mesmo que gaguejante, faz parte da condição humana) e ao mesmo tempo não pode ficar do modo como está. A partir daí vêm as tentativas de acertos na fala, acarretando tensões e comportamentos muitas vezes não aceitos pelo meio social, criando a visão estigmatizada. Assim, a gagueira sofrimento vem a constituir-se como um reflexo do olhar do outro sobre o padrão de fala disfluente da criança, sendo esse olhar, por sua vez, reflexo de uma representação estigmatizada da disfluência.

Azevedo e Freire (2001) relacionam a chamada disfluência normal de fala ao processo de aquisição de linguagem, desdobrando sua elaboração a partir dos pressupostos desenvolvidos por De Lemos $(1995,2002)$ em relação a esse processo. 
O Projeto Interacionista em aquisição de linguagem, desenvolvido por De Lemos (1998), afirma ser este processo - da aquisição de linguagem - marcado por mudanças de posições discursivas da criança em sua relação com o outro, entendido como funcionamento de linguagem. A posição discursiva que indicia o deslocamento da criança em relação a sua fala e à fala do outro, é marcada pela ocorrência de pausas, reformulações e autocorreções em sua própria fala, levando a criança a colocar-se na posição em que é interpretada, ou seja, na de falante. Se, no entanto, esses erros, ao invés de serem reconhecidos como formas de assemelhamento da fala da criança à fala do outro, forem interpretados como gagueira, poderão gerar outros efeitos. ${ }^{1}$

Os autores aqui citados, em sua maioria, partem do pressuposto de que a origem da gagueira é inerente à constituição do sujeito ou ao seu desenvolvimento. Pode-se observar entre esses autores:

a) Convergência quanto à existência de um período anterior à gagueira e divergência quanto à nomenclatura usada para definir esse mesmo período;

b) Desproblematização dos fatores que levam ao desenvolvimento da gagueira ou ao seu desaparecimento;

c) Uso de parâmetros de quantidade e qualidade para diferenciar os sintomas do período anterior à gagueira e a gagueira propriamente dita.

A indefinição dessas questões levou-nos a tomar a posição adotada por Azevedo e Freire (op.cit.) para considerar diferentemente a chamada fase de disfluência normal de fala que, nessa perspectiva, é tomada como posição da criança em relação à língua - para, a partir daí, pesquisarmos, suportados pelo procedimento teórico-metodológico da Análise do Discurso de Linha Francesa, possíveis relações de implicação entre o discurso dos pais e a emergência da gagueira de seus filhos, voltando nossa atenção para a interpretação da fala da criança e seus efeitos na transformação da fluência desta mesma criança.

\section{AQUISIÇÃO DE LINGUAGEM E GAGUEIRA}

Embora todas as vertentes apresentadas tragam contribuições para a Fonoaudiologia, pela própria posição teórica que assumem há considerações que lhes escapam. Essas considerações, em sua maioria, referem-se à relação linguagem

1. Como veremos detalhadamente a seguir. 
e sujeito. Este é um dos motivos que nos levaram à Lingüística, a saber, o fato de que esse campo de conhecimento ilumina a questão do funcionamento de linguagem e, portanto, a relação linguagem e sujeito e a questão da origem da gagueira, possibilitando à Fonoaudiologia uma releitura da noção de disfluência.

Azevedo e Freire (2001), apoiando-se na perspectiva da Lingüística, em especial nos estudos que se detêm sobre a linguagem e seu funcionamento, reelaboram um espaço para se refletir sobre a gagueira e afirmam que esta se encontra no espaço intervalar, ou seja, não está nem no sujeito, nem no ouvinte, mas sim no discurso - a gagueira é tomada como um problema discursivo. É por meio do discurso - lugar do funcionamento da linguagem - que o sujeito vem à tona. Nos processos metafórico e metonímico - leis de composição interna da língua - é que o sujeito emerge, possibilitando a (re)significação dos significantes que aí circulam.

O Projeto Interacionista em Aquisição de Linguagem desenvolvido por De Lemos e pesquisadores defende a idéia de que o adulto e a criança estão submetidos ao funcionamento da língua; dessa forma, o adulto não é transmissor - embora tenha essa ilusão - e nem mediador, assim como a criança não é aprendiz.

Nessa visão, a opacidade da linguagem vem à tona, pois as elaborações lingüísticas, quando tomadas em sua singularidade e não mais objetivamente, apresentam conteúdos latentes, que vão além dos manifestos e, portanto, não são transparentes. Isso permite que se tenha uma visão mais criteriosa sobre a gagueira que, em outras concepções, dirige o trabalho terapêutico ao que é visível, ou seja, aos sintomas tomados em si.

De Lemos (1995) afirma que a aquisição de linguagem da criança ocorre pelo deslizamento (deslocamento) da fala do adulto para a fala da criança, estando esta sob o efeito da língua. O adulto, diante da fala da criança (que é composta por fragmentos da sua própria fala), interpreta-a, dando sentido e articulando-a a um texto. A criança tende a assemelhar sua fala à do outro.

Portanto, encontramos as seguintes posições discursivas que a criança ocupa na aquisição de linguagem:

1. "o fato de que a criança acerta, mostrando uma fala que contém fragmentos espelhados da fala do adulto, atesta que a criança se encontra circunscrita à fala do outro, em uma primeira posição de falante;

2. o fato de que a criança erra (após acertar) mostra um falante submetido ao movimento da língua, considerando 'os processos metafóricos e metonímicos como circunscritos a um efeito de semelhança ou espelhamento entre cadeias que, ainda que originárias do outro, ganhavam seu estatuto na língua, a saber fora da esfera do outro'

3. o fato de que há um desaparecimento dos erros, o que coincide com a ocorrência de pausas, reformulações e autocorreções, com reconhecimento dos erros; configura um deslocamento do sujeito falante em relação à sua fala e à fala do outro. Nesta 
posição também se observa o funcionamento dos processos metafóricos e metonímicos, uma vez que há o reconhecimento das substituições realizadas. Há um movimento de assemelhamento à fala do outro". (DE LEMOS, 1998, p.15);

Desse modo, em um primeiro momento, a criança alça significantes corretos da língua, não interpretados por ela, para, enfim, deslocar-se, dessubjetivando o adulto, momento em que passa de personagem à autora de seu processo (surgindo aí os erros). Há o efeito reorganizador da linguagem sobre a linguagem, à medida que a criança produz e ouve enunciados. As autocorreções são, portanto, mudanças da posição de interpretado para intérprete, de si mesmo e do outro.

\section{GAGUEIRA}

A formulação apresentada acima foi retomada na pesquisa de Azevedo e Freire (2001) como lugar onde refletir sobre a emergência da gagueira. Dessa forma, essa emergência pode ser localizada no terceiro momento do processo de aquisição de linguagem, quando podem ser observadas, nas produções das crianças, a ocorrência de pausas, reformulações e autocorreções. Essas pausas, reformulações e autocorreções assemelham-se às repetições e hesitações que caracterizam a gagueira, gerando movimentos de estranhamento na interpretação do Outro. Esse estranhamento pode levar o Outro a atribuir a essas repetições, pausas e hesitações na fala da criança, o estatuto de gagueira, ou seja, a cristalizar o manifesto, aprisionando-o ao patológico. $\mathrm{O}$ adulto pode interpretar a fala da criança, quando nessa posição, como gaguejante. Assim, não havendo assemelhamento entre a fala da criança e a do Outro, aquela depara-se com a diferença, podendo ocupar a posição de sujeito gago, ao ser silenciada por esse Outro.

Embora Azevedo e Freire (op. cit.) não tenham como objetivo discutir a origem da gagueira, ressaltam a singularidade do discurso dos pais (ou cuidadores) das crianças gagas, visto que, segundo seus estudos, esses discursos se caracterizam como autoritários e tensos, que colocam a criança em uma relação de ordem de cima para baixo. Esse discurso, segundo as autoras, é dominado pela ausência de reversibilidade. "Esta fala do adulto ao recusar sentido à fala que se presentifica por repetições, hesitações, silêncios e reformulações, distancia a criança da posição discursiva de reconhecimento ou identificação do erro" (op. cit, p.9).

Segundo De Lemos (1998), o deslocamento da criança na língua ocorre quando o adulto reconhece sua produção oral como linguagem e a interpreta como tal. 
Sendo assim, podemos dizer que a interpretação do Outro à fala da criança é um fator importante - mas não único - para que o processo de aquisição de linguagem caminhe, permitindo-lhe deslocamentos. A esse fator associa-se o efeito dessa interpretação sobre a criança, ou seja, no caso de a interpretação colocála na posição de sujeito gaguejante, a criança poderá ou não cristalizar-se nesse espaço - sobredeterminação do discurso. Assim, caso se veja como gaga, a criança poderá acabar assumindo essa condição. Se o fizer, será desta posição que será (re) significada.

Estas considerações vão ao encontro desta proposta, que pretende tomar esse momento, caracterizado por pausas, hesitações e reformulações dos sons na produção oral, ao reconhecer nele os fatos empíricos que levaram os pesquisadores a atribuir-lhe o sentido da Disfluência Normal de Fala (ou quaisquer outras denominações) para (re)significá-lo à luz da teoria.

\section{ABORDAGEM TEÓRICO-METODOLÓGICA}

A Análise de Discurso de linha francesa, segundo Orlandi (1994), tem como objeto de estudo o discurso e, diferentemente do Projeto Interacionista, a AD admite uma autonomia de linguagem relativa, já que leva em conta a relação entre o dizer e a exterioridade, ou seja, as suas condições de produção. Essa relação constitutiva entre o discurso e sua exterioridade é a marca fundamental da AD. É nessa relação que está a possibilidade de se encontrarem regularidades no domínio discursivo. O termo regularidade é utilizado para distinguir-se de regra categórica. Segundo Orlandi (1986), as regularidades, diferentemente das regras categóricas, "não são formuláveis nem quantitativamente (como resultado de uma certa freqüência), nem sob o modo de notação formal" (p.122).

Para se encontrar as regularidades de seu funcionamento, todo discurso deve, assim, ser remetido à sua formação discursiva que, por sua vez, se define pela relação (qualquer) que tem com a formação ideológica.

Cabe à $\mathrm{AD}$ analisar os processos característicos de uma formação discursiva que devem dar conta da articulação entre o processo de produção de um discurso e as condições em que ele é produzido. $\mathrm{Na} \mathrm{AD}$, marcas ou pistas são objetivadas. Para atingi-las, é preciso teorizar. Segundo Orlandi (1988, p. 18), "a relação entre as marcas e o que elas significam é tão indireta quanto é indireta a relação do texto com as suas condições de produção. No domínio discursivo não se pode, pois, tratar as marcas ao modo positivista como na lingüística". Assim, essas marcas, 
que atestam a relação entre o sujeito e a linguagem no texto, não são detectáveis mecânica e empiricamente.

Ao se analisar um funcionamento discursivo, não basta apenas determinar as suas marcas formais. Por isso Orlandi (1988) introduz uma distinção entre marcas e propriedades do discurso. De acordo com a teoria: "marcas dizem respeito à organização interna do discurso e propriedades têm a ver com a totalidade do discurso em relação com as suas condições de produção" (p.121).

Em suma, Orlandi (1986, p. 111) relata: "a AD objetiva mostrar - quanto ao sujeito, a relação mundo / linguagem e ao sentido - que estes não são transparentes e que devem ser pensados em seus processos histórico-sociais de constituição". Assim, a AD toma por base o discurso como acontecimento, enquanto efeito de sentidos entre locutores, e propõe a noção de funcionamento, ou seja, a relação existente entre condições materiais de base - a língua - e o processo - o discurso. A formação discursiva media, de um lado, as condições de produção e o funcionamento discursivo e, de outro, a formação ideológica do falante.

A linguagem na AD é considerada fato e não dado, por estar no interior de um sistema e considerar as condições de produção (quem fala, por que fala, para quem fala...). Além de levar em conta as estruturas, analisa o sentido da fala do sujeito, considerando as intenções do falante. $O$ falante, ao enunciar, o faz por apresentar, inconscientemente, a ilusão de ser autor do seu dizer.

A noção de esquecimento adotada de Pêcheux tem uma função essencial, sem a qual permaneceria incompreensível a ilusão, para o sujeito, de estar na origem do sentido que ele enuncia. De acordo com Orlandi (1994), para falar de esquecimento é necessário falar sobre a natureza do conceito de sujeito na AD. O sujeito nessa abordagem - "forma sujeito - é a de um sujeito autônomo e responsável, com deveres e direitos. A forma sujeito resulta de processos de identificação em que se joga o esquecimento, constituindo a chamada ilusão objetiva. O sentido aparece como já sendo sempre um sentido e o sujeito como sempre já-lá, para que possa dizer" (p. 302).

Os esquecimentos marcados na $\mathrm{AD}$ são:

1) Esquecimento número um (total): o homem esquece que não é a origem do seu dizer (isso para que ele possa se colocar no seu enunciado);

2) Esquecimento número dois (parcial): o homem acredita que aquilo que diz é real (e não simbólico). Esse esquecimento é parcial, visto que o homem pode ter certa percepção a esse respeito. 
É importante ressaltar que a $\mathrm{AD}$ procura atingir a ilusão acima citada, desfazendo sua eficácia, mostrando como ela é produzida. Por isso é importante dar lugar às sistematicidades lingüísticas na $\mathrm{AD}$. Pois é no ponto de articulação da língua com a ideologia, ou seja, no discurso, que se produzem os mecanismos dessa ilusão.

\title{
4. A ANÁLISE DO DISCURSO ENQUANTO PROCEDIMENTO DE ANÁLISE
}

De acordo com Orlandi (1994), a análise de um discurso passa por três etapas: a) superfície lingüística; b) objeto discursivo; e c) processo discursivo.

Para a AD funcionar é necessária a ultrapassagem da superfície discursiva (que é o texto), fazendo-se um recorte para se alcançar o objeto discursivo e, assim, os processos discursivos.

\begin{abstract}
"Para passarmos de $a$ para $b$ (grifos nossos) trabalhamos uma forma de análise que opera com o esquecimento número dois (o da enunciação) e chegamos ao delineamento da diferença entre distintas formações discursivas. Aí intervém o conhecimento lingüístico, do nível da formulação (intradiscurso). Como resultado, obtemos o objeto discursivo, que já não é o material lingüístico bruto, afetado pela ilusão subjetiva. Em seguida, passamos para nova etapa de análise, a que nos leva de $b$ para $c$ (grifos nossos). Nesta etapa se trabalha o objeto discursivo em direção ao processo discursivo, em que se instala já mais especificamente o jogo ideológico: aí trabalhamos com o esquecimento número um (o da ideologia). Estamos nesta etapa no jogo complexo do conjunto das formações discursivas em sua relação com a ideologia. Aí já se desenha a definição ideológica dos discursos e trabalhamos no nível da constituição do discurso (interdiscurso). É a etapa em que nos instalamos de forma plena no processo discursivo e, assim sendo, já podemos chegar à compreensão do discurso que é o objeto de análise, isto é, já estamos em medida de compreender como aquele material de linguagem produz sentidos. A esta altura da análise já temos explicitados os mecanismos de funcionamento do discurso que é objeto de nossa investigação" (ORLANDI, 1994, p.303).
\end{abstract}

Ao analisar um funcionamento discursivo, além determinar as suas marcas formais, há necessidade de se trabalhar também as propriedades do discurso. O acesso às marcas e propriedades dá-se por meio dos recortes, ou seja, pelas unidades discursivas que se constituem de fragmentos correlacionados de linguagem e situação; dito de outra forma, pelos fragmentos da situação discursiva.

A interpretação sempre está atravessada pelo lugar histórico e social que o sujeito ocupa. A interpretação na $\mathrm{AD}$ está no lugar do efeito metafórico, enquanto deslize de sentidos, lugar dos equívocos. Ressaltando tais deslizes, a AD visa compreender o discurso do sujeito, considerando que qualquer objeto simbólico 
pode ser fonte de sentidos. Os discursos podem ser organizados em três tipos. São eles:

Discurso autoritário: dirigido por quem fala; caracterizado pela nãoreversibilidade. Este tipo de discurso tende a silenciar o outro, negando-lhe a ocupação de diferentes posições e fazendo com que fique estanque em um lugar - produzindo sentidos não proibidos.

Discurso polêmico: o referente muda de direção; ao mudar de direção, o discurso se transforma, se modifica;

Discurso lúdico: é o discurso da brincadeira, do non-sense, da ironia (no sentido de ir contra ao que se quer dizer).

Como será observado a seguir, uma das marcas de todos os discursos dos pais das crianças gagas foi o seu viés autoritário.

\section{ANÁLISE DE DADOS}

Em busca de indícios da implicação do discurso dos pais na estruturação da gagueira de seus filhos, foram realizadas quatro entrevistas, às quais compareceram apenas as mães de quatro crianças: R., 10 anos; T., 10 anos; F., 11 anos e L., 11 anos (estes dois últimos, são gêmeos). Essas entrevistas foram analisadas dentro do procedimento da Análise de Discurso de Linha Francesa. É importante ressaltar que esta pesquisa incidiu sobre o discurso de mães cujos filhos eram por elas tidos como gagos, procurando nele, marcas ou propriedades discursivas que pudessem ser articuladas à fala de seus filhos.

Passamos a apresentá-los, organizando-os em grupos discursivos:

a) Discursos que significam a fala das crianças dentro de uma perspectiva temporal em que aparece a contraposição entre uma fala rápida (com gagueira) e o seu oposto - a fala devagar - pressuposta pela mãe como forma de superação da gagueira.

Mãe de R.:

"(...) en mando ele ficar calmo, eu às vezes eu fico, en acabo perdendo a paciência também, sabe, e eu quero que ele fale devagar, ele já é ... e acaba não saindo nada. Então é isso aí que..."

"(...) daí ele até brinca assim, que ele falou: 'Mãe, se eu arrumar uma namorada antes de eu casar, mãe, se eu atrasar 
cinco minutos, antes de eu abrir a boca eu já estou apanbando, sem saber por que, porque não deu tempo de eu falar tudo'. Então ele tá lutando, pra falar a verdade".

Mãe de T.:

"Ó, tem bora que ele fala normal, mas tem hora, quando ataca, demora a falar, aí ele fica enro... querendo falar coisa, e fica batendo, chutando, pra poder sair a palavra, mas só que demora muito pra sair."

"Olha, eu mando ele ter calma, esperar, pra depois ele falar, senão ele não consegue falar nada".

"Deve ser porque ele fica, tem bora que ele fica nervoso, que acho que demora mais dele saí a voz ou então porque tem bora que ele fala que tem vergonba de falar as coisas, né, por causa da gagueira, né. Mas demora bastante, demais, muito mesmo. Pra ele falar mãe, tem hora que...nossa! Demora muito pra falar mãe".

Mãe de L.:

"Ele fala, ele mesmo, ele fala muito enrolado, sabe, às vezes ele, ele mesmo não entende, ele não sabe como que ele falou. Ele fala, você tem quefazer ele repetir umas três vezes, porque no meio, assim, da conversa, ele enrola. Então você não entende o que ele falou, você tem que parar e falar: 'Filho, L., fala isso de novo que eu não estou entendendo'. Ai ele... porque ele fala muito rápido, sabe?"

"Eu mando ele se acalmar, en falo: 'L., pára, depois você fala com a mamãe, não precisa ficar assim'. Aí ele se acalma, aí depois ele fala".

As mães apresentam, em seus relatos, duas queixas contraditórias e simultâneas: uma refere-se à rapidez da fala de seus filhos e a outra à demora destes em falar. Essa questão de tempo é atribuída ao ritmo da fala da criança.

A mãe de R. relata que a criança lhe diz que acredita não ter tempo suficiente para falar; ainda assim, ao falar, é silenciada pela mãe que o manda ter calma, para que seja possível entendê-lo. A mãe relata que as produções orais de seu filho demoram muito a sair; no entanto, não pode ouvi-las quando são ditas, a não ser que a criança fale após uma pausa que lhe é solicitada.

A mãe de L., diferentemente, relata que seu filho fala muito rápido. No entanto, à semelhança da mãe de R., pede-lhe calma antes que se coloque na posição de escutá-lo.

b) Discursos em que o significante gagueira é afetado por uma operação metonímica ou metafórica.

Mãe de R.:

"Bom, o R. ele começou... eu senti que ele já tinba um pequeno problema a partir... quando ele começou a falar as primeiras palavrinhas".

"Aí então aquilo já me irritava porque, conforme ele ia tentar falar alguma coisa e não saía, eu já ficava nervosa". 
Mãe de T.:

"Ab... eu pensei que era normal aquilo, acabava, né?"

"...tem vez que não sai tudo, né, direitinbo, mas tem bora que ele vai falar, ele não sai direito a palavra".

"Ia fazer, ainda, quando começou" (omissão do objeto).

"Não, só depois com a idade de quase nove anos que ele começou a dar mesmo".

Mãe de L.:

"Ele fala, ele mesmo, ele fala muito enrolado, sabe, às vezes ele, ele mesmo não entende, ele não sabe como que ele falou. Ele fala, você tem que fazer ele repetir umas três vezes, porque no meio, assim, da conversa, ele enrola. Então você não entende o que ele falou, você tem que parar e falar: 'Filho, L., fala isso de novo que eu não eston entendendo'. Aî ele... porque ele fala muito rápido, sabe".

Mãe de F.:

"A fala do F...é mais desenrolada".

Em todos os discursos analisados, presentificou-se o apagamento ou a substituição do significante gagueira. As substituições, metonímicas ou metafóricas - deslocamentos discursivos - recalcam o significante gagueira. Esse fato leva a pensar no efeito do recalque do significante para a família e para o próprio gago. Do mesmo modo que o significante gagueira é silenciado - recalcado - na fala das mães, a gagueira, em muitos momentos, é silenciada na fala da criança, presentificando-se em momentos de silenciamento da própria criança.

Para a mãe de R. a gagueira é descrita inicialmente como um "pequeno problema", tornando-se, com o passar do tempo, "aquilo" - um acontecimento que a irrita demais, tanto que não consegue nomeá-lo; ao mesmo tempo em que é tão visível que não necessita de nomeação - como se qualquer um soubesse a que ela se refere.

Para a mãe de T., "aquilo" era normal. Na sua fala presentificam-se, no lugar da nomeação da gagueira, dêiticos e orações com sujeito oculto, como quando diz "ia fazer, ainda, quando começou". Além dessas substituições, ocorre uma outra que leva à confusão, no discurso da mãe, entre o filho e sua produção oral. Quando a mãe diz: "ele não sai direito a palavra" por "não sai direito a palavra dele" ou "ele começou a dar mesmo" por "algo começou a dar nele," há combinações não permitidas em nossa língua, indícios do efeito de estranhamento da gagueira no discurso da mãe.

c) Para a mãe de L. e de F., a gagueira é entendida como um enrolamento de sua fala que pode ser quantificado. Seu filho L. é mais gago, visto que "fala muito enrolado", enquanto que F. não é um caso tão grave, porque sua fala é mais "desenrolada" - e, portanto, menos gaguejada. Discursos autoritários que tiram o gago da cena discursiva e o destinam ao silenciamento. 


\footnotetext{
Mãe de R:

"Eu mandava parar. Eu mandava parar porque eu não tinba paciência de ficar, sabe, até ele tentar falar a palavra, então eu não tinha muita paciência na época".

"...se ele às vezes ele chega afobado, então eu prefiro que ele se acalme pra conversar comigo e se ele tá assim com medo, alguma coisa, eu também prefiro também que ele se acalme pra falar comigo, porque se for falar assim na...comigo, en já fico nervosa, porque acaba não saindo nada".

Mãe de T.:

"Otha, eu mando ele ter calma, esperar, pra depois ele falar, senão ele não conseque falar nada".
}

Mãe de L.:

"Eu mando ele se acalmar, eu falo: 'L., pára, depois você fala com a mamãe, não precisa ficar assim'. Aí ele se acalma, aí depois ele fala".

Mãe de F.:

"Não. O F. tem a mania de ficar mudo. Você fala com ele, se ele fica nervoso, ele fica mudo".

O discurso endereçado à criança caracteriza-se por ser autoritário. Assim, não é permitido ao Outro escutar a criança, que tende a ficar silenciada diante desse tipo de discurso.

Nesses recortes, há um privilégio da forma que toma o dizer em detrimento do sentido que pede interpretação. A escuta das mães privilegia, assim, a cadeia estrutural desse dizer, negando sentido ao discurso.

A mãe de R. justifica sua dificuldade em escutar seu filho e em abrir espaço para que ele fale pela sua "falta de paciência e nervosismo". Embora em seu relato diga estar atualmente mais calma em relação a R., seu discurso caminha na direção de impedi-lo de assumir o papel de falante, posição esta que a criança assume com sua tia, segundo dados da mesma entrevista.

A mãe de T., assim como a de R., pede calma ao filho, entendendo que isto o levará a falar direito, como se o tempo fosse um aliado da boa produção oral. Silencia-o, mandando-lhe esperar que se acalme, sem levar em conta o desejo do filho de posicionar-se como falante.

A mãe de L. e de F. posicionou-se diferentemente em relação a cada um de seus filhos. Para o filho que interpreta como sendo "o mais gago," pede calma durante sua produção oral, como se do ritmo lento derivasse uma fala mais fluente. Afirma que os efeitos da gagueira sobre F., seu filho "menos gago", são outros. Ao antecipar que poderá apresentar uma fala 'alterada' que será silenciada, antecipa esse silenciamento, calando-se diante do outro. 
d) Discursos marcados pela contradição na caracterização dos filhos.

O primeiro recorte refere-se à mãe de R.. Seu relato é tramado pela descrição de diversas características de seu filho, em sua maioria, contraditórias. No início de seu texto, a mãe relata que $R$. não tem dificuldades em lidar com as pessoas, justificando esse fato com a seguinte fala: "ele é até sossegado até demais". Mais adiante, ao relatar o desejo do filho em "tratar-se", o que já indicia seu incômodo, expressa a afobação da criança, caracterizando-a como "afoito (...) afobado". A mãe descreve o receio de R. gaguejar quando entre amigos e, conseqüentemente, a preocupação de afastar os outros dele. Entretanto, embora sinalize que seu filho tende a se afastar das pessoas, descreve-o como "muito fácil de fazer amizades".

Mãe de R:

"Eu sempre mando ele não não ligar, sabe, eu todo, desde quando ele entrou no colé..., na escolinba, en falei pra ele: 'Vai ter muitas pessoas que vai rir de você, vai achar engraçado seu modo de falar, sabe, outras vão...vãa... depois isso é só no começo, depois isso vai passar, sempre depois acaba se acostumando... se você não ligar, eles vão ver que você não ligou, isso vai passar; agora se você der corda, aí é que eles vão ficar te enchendo as paciência'. E ele é assim, ele é muito sossegado (...) Muito trandüilo, não é de procurar confusão, ele é até sossegado até demais".

"E aí ela... ele ficou, sabe, ficou tipo/tipo assim, afoito, aí... 'Será que eu vou pará de gaguejar boje?' Eu falei: 'Não é assim'. (...) E ele ficon afobado pensando que era pra ele vir hoje, ele falou: "Mãe épra eu ir?".

"Eu... ele agora tá fazendo inglês, também, só que... ab... ele tá meio receoso, já por causa sabe, disso. Porque na hora tipo da/da, de alguma tradução, do diálogo, ele começar a gaguejar e já é outra turma, já não é da mesma dele, já começar novamente a... a... tirar sarro, essas coisas. Mas ele/ele é muito assim, interesseiro, ele gosta, assim, de querer falar bem. Ele tem força de vontade. Tem. Ele tá com muita força de vontade pra poder para..."

"Se enturma, se enturma. Ele é muito fácil de fazer amizade, muito fácil mesmo".

A mãe de L., como a de R., ao se referir ao filho, ao mesmo tempo em que chama a atenção para a tranqüilidade da criança, indicia o que nomeia de agressividade e nervosismo.

Mãe de L.:

"Bom, o L. é um menino tranqüilo, né?"

"Como que ele é, assim... de comportamento? Ab, sim, o comportamento dele, ele é assim, um ponco adressivo né? Ele é uma pessoa inquieta, assim... (...) Ele é nervoso".

e) Discursos em que a causa da gagueira é atribuída aos pais ou à família.

Mãe de R.:

"É, foi assim, é... tipo assim, eu, às vezes as pessoas, muitas pessoas chegaram a conversar comigo, né, porque eu nunca fui assim, vou te falar a verdade, eu nunca fui uma mãe assim, carinhosa, assim, de chegar, de agarrar assim, 
não, porque eu fui mãe muito cedo, eu tive ele aos meus dezesseis, então en enfrentei muita barreira, sabe, e... e... tipo assim, se às vezes ele chorava, então aquilo já me irritava, en gritava, en colocava ele de castigo, não queria saber, então muita gente às vezes acha que por causa deu gritar, de eu colocar de castigo, acha que ele ficou assim por meu, algum tipo de grito men que eu dei, alguma coisa assim e ele se assustou. Sabe, e aí, sei lá, e as pessoas chegam pra mim: 'Eles vão te culpar, eles vão te culpar'. E en falo assim: 'Não, o que tiver que acontecer, vai acontecer'. Só que eu não posso omitir o que foi que aconteceu mesmo, né, porque eu tava muito nova, o pai dele também tinha dezessete anos na época, sabe, então foi uma coisa assim...".

Mãe de T.:

"Ó, no começo a gente pensava que... era só porque o pai dele gagueja, né, aí eu pensei que era por causa disso".

Mãe de L. e F.:

"O L. chegou a ter bronquite nervosa porque o pai correu atrás de mim com uma faca, que ele queria me furar, sabe, e ele vendo aquilo começou a tremer e foi depois en levei ele no médico, o médico mandou passar no outro de bronquite e ele tava com bronquite, né, com uma bronquite nervosa e fez o tratamento, Deus ajudou que ele ficou bom, sabe, mas ele ficou assim, com esse negócio do pai na cabeça, sabe, sempre quando o pai falava alterado comigo ele já ficava assim nervoso, já começava... acho que por causa do nervoso (SI)".

"Por isso que eu acho que é por causa do nervosismo deles com o pai, né, por causa das boras que eles viam o pai me agredir, assim, eles ficava nervoso".

Em relação à causa da gagueira, as mães atribuem sua origem, quer diretamente a si, quer ao seu cônjuge. Ao serem questionadas sobre a causa da fala gaguejada de seus filhos, todas relatam algum acontecimento familiar inerente à história de suas vidas ou alguma característica do funcionamento familiar como justificativa para essa alteração na fala. Em nenhuma das entrevistas as mães manifestaram desconhecimento ou dúvida em relação a essa questão.

f) Discurso caracterizado pela desarticulação, como efeito da fala de seu filho ${ }^{2}$.

A gagueira de R. é remetida, por sua mãe, à história de sua vida (M11).

M11: "Bom, esse pequeno problema que eu te falei, conforme ele começou a falar? É, foi assim, é... tipo assim, eu, às vezes as pessoas, muitas pessoas chegaram a conversar comigo, né, porque eu nunca fui assim, vou te falar a verdade, eи nunca fui uma mãe assim, carinhosa, assim, de chegar, de agarrar assim, não, porque eu fui mãe muito cedo, en tive ele aos meus dezesseis, então en enfrentei muita barreira, sabe, e... e... tipo assim, se às vezes ele chorava, então aquilo já me irritava, en gritava, eu colocava ele de castigo, não queria saber, então muita gente às vezes acha que por causa deu gritar, de en colocar de castigo, acha que ele ficou assim por meu, algum tipo de grito men que en dei, alguma coisa assim e ele se assustou. Sabe, e aí, sei lá, e as pessoas chegam pra mim: 'Eles vão te culpar, eles vão te culpar'. E eu falo assim: 'Não, o que tiver que acontecer, vai acontecer'. Só que eu não posso omitir o que foi que

2. Esta marca manifestou-se apenas no discurso da mãe de R. 
aconteceu mesmo, né, porque eu tava muito nova, o pai dele também tinba dezessete anos na época, sabe, então foi uma coisa assim...".

Observa-se no discurso da mãe de R. que este, ao gaguejar, é silenciado (M16) pelo discurso autoritário que estrutura o seu dizer (M14).

M16: "A h, não. Eu mandava parar. Eu mandava parar porque eu não tinba paciência de ficar, sabe, até ele tentar falar a palavra, então eu não tinba muita paciência na época".

M14: "Já desde a ... do começo. Aí eu falava: 'Não éassim, épapai, épapai, é mamãe' ... e não saía, sabe, aí é que ele ficava afoito e aí não saía nada".

Ao mesmo tempo em que a mãe relata, atualmente, estar se relacionando bem com o filho (M21), continua sem suportar a gagueira dele (M32), porque, para ambos, a gagueira é um mal (M38).

M21: "Muito com a minba irmã... demais. Ela pu.., assim tipo assim, assim, dia de sexta-feira ele vai dormir lá, aí eu sempre vou buscar ele no domingo, então quando eu chego lá ela sempre me conta muitas coisas dele, mui... apesar que ele se abre, nossa, agora o nosso relacionamento melhorou bastante mesmo né. Sabe que eu, porque, sei lá, en tinha certa frieza, sabe?"

M32: "Isso. Depende muito assim, se ele, às vezes ele chega afobado, então eu prefiro que ele se acalme pra conversar comigo e se ele tá assim com medo, alduma coisa, eu também prefiro também que ele se acalme pra falar comido, pordue se for falar assim na... comigo, en já fico nervosa, porque acaba não saindo nada".

M38: "Só por causa disso e eu, en fui logo estourada no dia da reunião porque ela olbou pra mim e falou assim: 'Por que que ele é gago?' Eu falei pra ela: 'O que eu posso explicar pra senhora? Eu não sei e eu acho da maneira que a senhora se comportou com men filho aqui, na frente de todo mundo, ele gaguejando, ele começou a chorar'... E ela falou assim: 'Pode parar e pode continuar lendo'... e os meninos chamando ele de gaguinbo, de um monte de coisa, sabe, então foi mais... dele olhou pra mim, chegon em casa e falou: 'Mãe, en quero ficar bom'! Só isso que ele falou pra mim, eu falei: 'Então tá'".

Do mesmo modo, enquanto a mãe pede ao filho para "não ligar" para a gagueira dele (M33), ela própria não consegue vê-lo como falante (M32).

M3з: "Ab, sim. Eu sempre mando ele não/não ligar, sabe, eu todo, desde quando ele entrou no colé..., na escolinba, eu falei pra ele: 'Vai ter muitas pessoas que vai rir de você, vai achar engraçado seu modo de falar, sabe, outras vão... vão... depois isso é só no começo, depois isso vai passar, sempre depois acaba se acostumando... se você não ligar, eles vão ver que você não ligou, isso vai passar; agora se você der corda, aí é que eles vão ficar te enchendo as paciência'. E ele é assim, ele é muito sossegado".

3. Esta marca manifestou-se apenas no discurso da mãe de L. e F. 
g) Discurso marcado pela regularidade de uso do significante "né".

$\mathrm{O}$ alçamento desse significante deu-se, provavelmente, como efeito do discurso da entrevistadora, marcado pelo autoritarismo. Os "nés" utilizados marcaram um pedido de confirmação e escuta à fala da mãe, colocando a entrevistadora na posição de quem poderia fazer algo pelo seu dizer, dando-lhe uma direção ou sentido. Esse discurso deveu-se às condições de sua produção, pois a mãe, ao iniciar a entrevista, manifestava-se temerosa em falar³.

\footnotetext{
M1: "Bom, o L. é um menino tranqüilo, né?" (começou a chorar)

M2: "Como que ele é, assim... de comportamento? Ab, sim, o comportamento dele, ele é assim, um pouco agressivo, né? Ele é uma pessoa inquieta, assim..."

M11: "Quando a gente pede, porque ele quer falar assim muito rápido, sabe, ele não tem muita paciência, então ele quer falar rápido, aí você não entende o que ele falou, né?"

M32: "Encaminbou os dois. Ela falou: 'Eu vou encaminhar os dois porque a senhora já aproveita e se for o caso já encaixa os dois, né, se for o caso de operar, assim, de alguma coisa, então, porque à medida que eles vão crescendo, eles vão enrolando mais a linguagem, né? E como eles são inteligente, fica feio, né? ’"

M37: "É difícil a gente ficar assim lembrando de tudo que ele faz, né? E é difícil também lembrar do que você vai precisar".

M48: "Não, ele, ele... balança o ombro, née?"

M53: "Isso. Ele percebe que ele tá falando errado, então ele já prefere não responder, né? Fica quietinbo".

M59: "Só eles mesmo, viu? Por isso que eu acho que é por causa do nervosismo deles (seus dois filhos) com o pai, né, por causa das boras que eles viam o pai me agredir, assim, eles ficava nervoso".
}

\section{CONCLUSÃO}

Esta pesquisa partiu dos estudos apresentados por Azevedo (2000) e Azevedo e Freire (2001) que propõem a gagueira como efeito discursivo da interpretação do Outro. As autoras afirmam que o adulto, ao interpretar a fala da criança como gaguejada (e, portanto "errada"), alça um discurso predominantemente autoritário, que pode impedir a criança de assemelhar-se à fala do Outro, afetando o seu deslocamento. Assim, a fala hesitante da criança, indício de sua posição no processo de aquisição de linguagem, pode vir a tornar-se gaguejante. Na análise de dados, foi possível observar diversas marcas discursivas que nos permitiram interpretar algumas de suas propriedades: a perspectiva temporal na busca da localização da fala gaguejante das crianças pelas mães; o apagamento do significante gagueira; a prevalência do discurso autoritário, tendo como efeito o silenciamento do gago; e o reconhecimento dos pais como sendo eles os responsáveis pela gagueira. 
As mães apresentaram, em seus relatos, uma queixa contraditória e simultânea. Essa queixa refere-se à rapidez da fala de seus filhos contraposta à sua lentidão. A fala das crianças é interpretada, portanto, dentro de uma perspectiva temporal, em que a fala rápida é identificada à gagueira e seu oposto - a fala lenta - à fluência.

Vale lembrar, aqui, que Scarpa (1995), em seu estudo sobre a fluência e disfluência do sujeito, afirma que o conceito de fluência se encontra em seu oposto, isto é, a fluência é definida pelo seu contrário: o termo não marcado, ideal, produtivo, enquanto a disfluência é uma abstração, na medida em que a linguagem apresenta, por sua constituição, características de falta e incompletude.

Os discursos das mães foram marcados pela substituição do significante gagueira por um deslizamento metafórico ou metonímico, ou mesmo pela sua omissão - apagando-o e recalcando-o. Esse aspecto levou-nos a pensar no sentido que esse recalque do significante tem para a família e para o próprio gago. Do mesmo modo que o termo gagueira é silenciado - recalcado - na fala das mães, a gagueira, em muitos momentos, é silenciada também na fala da criança, presentificando-se silenciamentos por parte desta.

O discurso apresentou-se marcado pelo autoritarismo, silenciando a criança no momento da sua produção disfluente e, portanto, evitando escutá-la. As mães privilegiaram a forma que toma o dizer em detrimento do sentido que fica sem interpretação. A escuta das mães privilegia, assim, a forma e a estrutura desse dizer, postergando a doação de sentido ao discurso.

Em relação à causa da gagueira, as mães da pesquisa a atribuíram a si próprias, ao pai e ou aos familiares. Ao serem perguntadas sobre as razões da gagueira, todas relataram algum acontecimento familiar (história de vida delas próprias) ou característica do funcionamento familiar que justificasse essa alteração na fala de seus filhos. Em nenhuma das entrevistas a mãe se mostrou hesitante em relação a essa questão.

A análise permite afirmar que se verificou uma relação de implicação entre a interpretação do Outro e a fala da criança - em determinada posição do processo de aquisição de linguagem - e seus efeitos na fala da criança - a gagueira - que aponta para a necessidade de circunscrever a posição da criança como suscetível aos efeitos da fala da mãe.

Entretanto, é possível afirmar que não é suficiente considerar apenas a interpretação que os pais fazem do dizer da criança para que seus efeitos impeçam o deslocamento dessa criança em seu processo de aquisição de linguagem. Para "explicar" a gagueira seria preciso tecer considerações a respeito da sobredeterminação simbólica da linguagem e de seu funcionamento - questão não 
abordada neste trabalho. Cabe citar, apenas, que o discurso é sobredeterminado simbolicamente, o que elimina questões sobre a gênese da gagueira. Sendo assim, é possível entender por que algumas crianças se deslocam da posição discursiva provisória que configura o processo de aquisição de linguagem, enquanto outras são aí aprisionadas. Por fim, mais uma questão merece espaço nesta conclusão: o nome utilizado para denominar a disfluência infantil em oposição à gagueira. Nesse sentido, em relação à nomenclatura Disfluência Normal de Fala e seus cognatos, é possível observar-se uma contradição teórica, uma vez que o termo disfluência caracteriza uma alteração ou distúrbio na fluência não podendo, portanto, abarcar um estado de "normalidade". Como pudemos observar no decorrer deste trabalho, a disfluência normal de fala, ou disfluência de desenvolvimento, ou ainda, gagueira fisiológica, nomeiam dizeres que a aquisição de linguagem aponta como característicos do processo. Enfim, ao pensar a gênese da gagueira, deve-se considerar a tríade: interpretação que o Outro faz da fala da criança, o que a criança escuta sobre a sua fala e a sobredeterminação simbólica do discurso, considerando a fase de repetições e hesitações da criança como inerente ao processo de aquisição de linguagem.

\section{REFERÊNCIAS BIBLIOGRÁFICAS}

ADAMS, M.R. (1988). Five-year retrospective on stuttering theory research and therapy: 1982-1987. Journal of Fluency Disorders. 13(6):339-405,.

ANDREWS, G. et al (1982/1983). Stuttering: a review of research findings and theories circa 1982. Journal of Speech and Hearing Disorders. 48(3):226-246.

AZEVEDO, N. P.G. (2000). Uma análise discursiva da gagueira: trajetórias de silenciamento e alienação da língua. Dissertação de Mestrado, PUCSP. São Paulo,

AZEVEDO, N.P.G.; FREIRE, R.M.(2001). Trajetórias de silenciamento e aprisionamento na língua: o sujeito, a gagueira e o outro. In: Friedman, S.; Cunha, M.C.(org.) Gagueira e Subjetividade: Possibilidades de Tratamento. São Paulo: Artmed Editora.

BLOODSTEIN, O. (1971). A bandbook on stuttering. Chicago: Ill National East Seal Society for Crippled Children and Adults,

DE LEMOS, C.T.G (1995). Língua e discurso na teorização sobre aquisição de linguagem. Letras de Hoje. Porto Alegre: 30(4):9-28.

(1998) Processos metafóricos e metonímicos: seu estatuto descritivo e explicativo na aquisição da língua materna. Trabalho apresentado na The Trento Lectures Workshop on Metaphor and Analogy, organizada pelo Instituto per la Ricerca Scientifica e Tecnologica Italiana em Povo. Inédito 
. (2002). Das vicissitudes da fala da criança em Cadernos de Estudos Lingüísticos, n ${ }^{\circ} 42$, Campinas, jan/jun, p.41-70

FRIEDMAN, S. (2004). Gagueira: origem e tratamento. $4^{\text {a }}$ ed. São Paulo: Plexus Editora. . (2009) Fluência de fala: um acontecimento complexo. In: FERNANDES, F.D.M.; MENDES, B.C.A.; NAVAS, A.L.P.G.P. (orgs). Tratado de Fonoaudiologia. $2^{\text {a }}$ Ed. São Paulo: Roca, 2009. p. 443-448.

GOMES, R.E.O. O segredo (d) enunciado: uma reflexão sobre a gagueira na criança,. Campinas, 1991 [dissertação de mestrado, PUC]

IRWIN, A. (1983). Gagueira: uma ajuda prática em qualquer idade. Trad.: de Lacerda, H. R. C. São Paulo: Martins Fontes.

JOHNSON, W. \& Associates (1959). The onset of stuttering. Minneapolis: University of Minnesota Press.

MEIRA, M.I.M. (1983). Gagueira: do fato para o fenômeno. $2^{\circ}$ ed. São Paulo: Cortez.

ORLANDI, E.P. (1986). Retrospectiva. D.E.L.T.A., 2(1):105-126.

. (1994). O lugar das sistematicidades lingüísticas na Análise de Discurso. D.E.L.T.A., 10(2):295-307.

ORLANDI, E.P.; GUIMARÃES, E. (1988). Unidade e dispersão: uma questão do texto e do sujeito. In: LANE, S.T.M. apres.: Sujeito e texto. São Paulo: EDUC, 31:17-35.

PORFERT, A.R.; ROSENFIELD, D.B. (1978). Prevalence of stuttering. Journal of Neurology, Neurosurgery and Psychiatry. (41):954-956.

SCARPA, E.M. (1995). Sobre o sujeito fluente. Cad. Est. Ling. Campinas, IEL, (29):163-184. VAN RIPER, C. (1982) The nature of stuttering. Englewood Cliffs, New Jersey: Prentice-Hall, Inc.

Recebido: 13/08/2010

Aceito: 05/03/2012 
